\title{
Legal Construction of the Principles of Voluntary Mortgage Warranty Transfer
}

\author{
I Nyoman Sumardika, Ni Komang Arini Styawati \\ Faculty of Law \\ Universitas Warmadewa \\ Denpasar-Bali, Indonesia \\ istayuan@yahoo.co.id
}

\begin{abstract}
The paper discusses the issues of whether or not a voluntary transfer of collateral by the debtor Bank is legal in line with the view of the legal aspects of the guarantee and the existence of the principles of voluntary transfer of the guarantee on mortgage in the amendment of Mortgage Legislation in the future. Normative legal approach and statute approach were utilized in discussing the issues in this study. Legal materials employed are the Law no. 4 of 1996 on the Mortgage Rights, Law no. 101998 on Amendment to the Law Number 7 of 1992 concerning Banking and a number of relevant literature, such as law, banking law, and law of agreement which is then analyzed based on descriptive, systematization and explanation steps. The findings showed that voluntary transfer of mortgage warranty by the debtor to the creditor is in accordance with legal aspect of Legal Guarantee if it is done during the implementation of the credit agreement on the reason that the debtor is in a state of unable to execute the payment or obligations agreed with the bank. Voluntary transfer shall be made by the debtor of the asset pledged to the bank and an agreement is formulated before the Notary by the Voluntary Assignment Deed or by other terms, such as the Deed of Financing Settlement Agreement (Obligations), and the pattern of settlement of the external disputes litigation or auction process is formally recognized in various laws and regulations. These provisions can form the basis for developing a dispute resolution pattern within the banking world in the framework of Mortgage Right Legislation renewal by adding one of the mortgage law principles, namely voluntary transfer principles.
\end{abstract}

Keywords—voluntary mortgage; warranty transfer

\section{INTRODUCTION}

Bank as a business entity that gives credit to its customers certainly trying to get a profit. In carrying out its business, the risks that may arise due to crediting can be no return of loans that have been given. Credit risk is the most potential risk of all potential bank losses. According to information from Bank Indonesia in the Credit Implementation Guidelines, banks, in conducting credit management must identify, measure, monitor, control credit risk, and ensure adequate capital availability and appropriate compensation for risks arising to protect the itself from loss.

To protect and secure public funds managed by banks channeled in the form of credit, banks should refer to the Law of Article 8 Number 10 of 1998 on the Amendment of Act Number 7 of 1992 concerning Banking, which determines that:

"In providing credit or financing based on sharia principles, commercial banks shall have confidence based on a thorough analysis of the willingness and ability and ability of debtors to settle their debts or to refund the financing in accordance with the contract".

Building on the explanation of such article, credit or financing provided by the bank contains risks, so that in every crediting or healthy financing should be based on the principle of prudence. To that end, before giving credit, the bank should conduct a thorough assessment on various aspects. The principle used in making such considerations is known as the Five C's of Credit Analysis or the $5 \mathrm{C}$ principle, which includes: Character, Capacity, Capital, Collateral, and Condition of Economy [1].

This $5 \mathrm{C}$ concept can in principle provide information on the good faith and ability to pay the debtor to repay the loan as well as other interest and expenses [2].

The banking world is a strategic institution in economic activity because it raises public funds and distributes it in the form of credit. The term credit comes from the Roman credere, meaning to believe. So someone who has earned a credit from a bank means he has earned the trust of the bank [2]. The system structure is oriented to solve decision problems. Firstly, a decision-making method based on cloud model is proposed. Then a decision-making framework and process are designed [3].

Credit granting by banks requires the terms set forth in a credit agreement. This agreement constituting the legal relationship shall in principle comply with the requirements of the validity of a treaty, namely an agreement, a qualification, a certain matter and a lawful cause, as provided for in Article 1320 of the Civil Code. With the fulfillment of the four conditions of validity of the agreement, then a treaty becomes lawful and legally binding for the parties who make it.

Problem loans for banks is a problem that until now there has not been a qualified formulation. The handling of problem loans by creditors is done through various approaches, both through litigation process and non-litigation approach, the result is still far from expectation. Meanwhile, with the 
increasing number of problem loans to emphasize the banking situation is difficult as a consequence, many new tips by the banks to collect non-performing loans [2].

Law No. 4/1996 concerning Land and Property Rights (UUHT), has regulated the manner in which creditors/banks face problem loans by giving creditors the right to execution of the object of mortgage by selling object of guarantee on its own power through public tender as affirmed in Article 6 UUHT stating that:

"If the debtor breaches the pledge, the first holder of the right shall have the right to sell the object of mortgage on his own power through a public tender and to take his receivable from the proceeds of sale [4]".

The above circumstances show that, if the debtor can no longer be used to fulfill the obligations in the agreement, saving the funds can be used by executives with the right of dependents. In the meantime, in practice, the definition is as easy and as straightforward as mentioned in other related laws and regulations.

Troughout its development, the bank's attempts to resolve bad loans were conducted through mediation efforts. The end result of mediation is an agreement between the debtor and the creditor through the voluntary surrender of collateral made by the debtor to the bank or the acquisition of the debtor's assets by the bank.

Mediation by banks in contradiction is normatively contradictory. This can be observed from the provisions set forth in Article 12 UUHT stating that the object of mortgage rights shall not be agreed to be owned by the creditor if the debtor breaches the pledge. Under such construction, UUHT technically ignores the promises given to creditors to have a mortgage object.

Business in the banking world is a high-risk business. The form of risk to the creditor is the existence of problem loans. Handling problem loans by creditors with litigation process approach brings results that are still far from expectations. Understanding the ramifications of inequality in entrepreneurship in relation to this paper's agreement a licher assessment of the government's role in small business lending [5]. Meanwhile, with the increasing number of nonperforming loans, it has positioned banks in difficult conditions and as a consequence new bank tips to collect problem loans are often presented [2]. Study on risk in credit cooperative banks is relevant from a theoretical perspective because it addresses new trends in the risk management literature, thus elucidating how ERM systems can be implemented to support dualpurpose organizations [6].

In progress, the settlement of non-performing loans is done through mediation efforts in the hope that an agreement between the debtor and the creditor through voluntary surrender can be established. There are two legal issues studied: are the voluntary surrender of collateral guarantee by the debtor to the Bank is constitutionally legal under the terms of the guarantee law? And how the construction of the principle of voluntary mortgage rights transfer in the amendment of the Mortgage Rights Law in the coming future?

\section{METHOD}

The approach applied in investigating the issues in this paper is the normative juridical approach to law through statute approach, conceptual approach and case approach to legislation. The legal materials used are the Law no. Law No. 4 of 1996 on Mortgage Rights, Law no. 101998 on Amendment to Act Number 7 of 1992 concerning Banking and other relevant literature, such as security law, banking law, and contract law which are then analyzed according to descriptive, systematization and expansion procedures. The analytical method used is qualitative analysis by describing legal facts according to legal issues that are studied, interpreted, disistematized, given the argument to get the conclusion. The purpose of this paper is to offer alternative concepts of problem solving for problem loans that are more efficient, legal and beneficial for debtors and creditors.

\section{RESULT AND DISCUSSION}

Theoretical basis used to examine the above problem is the Theory of Justice proposed by Rawls which asserts that the fundamental agreement reached is fair. In this context Rawls calls "justice as fairness [7]" characterized by the principle of rationality, freedom and equality. Furthermore it is explained that the principle of distributive justice is the principle of the greatest equal principle, implying everyone should have equal rights over the most extensive basic freedom, the same freedom for all people, including in the field of civil law, especially the legal relationship between the creditor and debtor in the agreement credit with guarantee of Mortgage Right

Guaranteed Rights are the security rights imposed on the land rights referred to in the Basic Law of Agrarian (UUPA), as follows, or any other objects which constitute a unity with the land, for the settlement of certain debts, which gives priority to a particular creditor to other creditor. From the definition, principal element of mortgage can be depicted such as deposit Rights is the right of guarantee for debt repayment; object of the Deposit Rights is the right to land in accordance with UUPA; mortgage rights may be imposed on the land (title to the land) but may also be charged with other objects which constitute a unity with the land; secured debt is a certain debt; and providing the preferred position to certain creditor to other creditor.

Furthermore, in Article 8 paragraph (1) UUHT, it is stated that the right person is an individual or legal entity that has the authority to do deeds to the object of related rights. Then in Article 8 paragraph (2) UUHT that the authority to perform legal acts against the Basic Insurance Rights in paragraph (1) must exist on the right of the Mortgage right upon registration of the Deposit Rights. In another part of the Law that is due to the birth of the Guaranteed Right is at the time of registration of the Deposit Rights, then the authority to perform the act of the Guaranteed Rights is emphasized on the Guaranteed Right when Drafting Book of Land of Mortgage Rights. Therefore, the validity of such authority must be verified at the time of registration of the relevant Mortgage Rights. Article 9 of UUHT the core of the Holders of Insurances is an individual or a legal entity domiciled as a debtor. 
Provision of credit facilities by the Bank to the prospective debtor is almost certainly always accompanied by the delivery of collateral, in the form of moving objects or immovable objects. Guarantee items that are most often submitted to the Bank are the Right to Land for binding by the creditor before the Notary/Land Deed Official (PPAT) with the Deposit Rights. In engaging in the bonding rights between the debtor and the creditor will sign the Deed of Assignment, with its ordinary characteristics of command, prohibition and permissibility. If the debtor's pledge to the creditor is a promise prohibited by law and the matter is promised then the promise is null and void [4].

Whenever granting the credits, the Bank and its customers typically agree to extend the facility grant period, repayment obligations, repayment schedule of principal and interest and other obligations to be fulfilled. If in its development the debtor is in arrears paying the principal and interest installments, then the condition indicates that the Bank will face credit risk (default risk). Risk settlement of non-performing loans is conducted through the usual process of guarantee execution under the provisions of the positive law in two ways: NonLitigation, Offsetting and Litigation through auction process of mortgage guarantee.

Strategy of executing mortgages is, in fact, not as easy as those specified in the Mortgage Law, as many problems arise so that the settlement of non-performing loans becomes impeded. Voluntary submission of collateral can be the best solution in the banking practice. This pattern is known as Collateral Taken Over means the assets acquired by the Bank, based on the voluntary submission by the owner of the collateral or by the power to sell outside the auction of the collateral owner in the event that the customer does not fulfill his obligations to the Bank.

The process of voluntary transfer of guarantee shall be valid if it complies with the provisions of the Mortgage Law whereby at the time of signing of credit agreement and guarantee binding shall not be promised that the bank in its position as the recipient of the mortgage can have the object of mortgage rights. This means the surrender of a guarantee of the Voluntary Rights is made after a condition of the borrower (mortgage providers) is apparent in the absence of payment. Positive law in Indonesia allows banks to buy part or all of the collateral either through auctions or outside auctions on the basis of voluntary submission by the owner of the collateral or by the power to sell outside the auction of the collateral owner in the event that the Borrower fails to comply with its obligations to the Bank, purchased must be disbursed as soon as possible. It shall be reviewed from Rawls's principle of distributive justice on the principle of the greatest equal principle [7], namely the principle of equality of rights, the delivery of collateral guarantee of voluntary rights by the debtor to the creditor is an implementation of the principle of freedom of contract. The principle of the greatest equal principle is the spirit of the principle of freedom of contract [8]. Epistemologically the word principle is often nurtured with the word "base or principle". This means that the word principle, principle or principle has almost the same meaning [9]. In Indonesian Big Dictionary it is defined as a pedestal of thought or opinion [10].
Guarantee of Mortgage Rights shall not be promised to be owned solely by the mortgagee if a promise of injury ", constitutes a legal principle adopting the principle of Mortgage in accordance with the provisions of Article 1178 of the Civil Code. Such promises are called vervalbeding. The prohibition of the inclusion of such a pledge, intended to protect the debtor, in order to be in a weak position in facing the creditor (bank) because in a state of urgent need of debt (credit) was forced to accept the promise with severe conditions and harm [10].

The principle of voluntary transferring of the mortgage right may actually be complementary to the Vervalbelding principle, provided that at the time of signing of the Mortgage Rights Deed, the delivery of a collateral guarantee is not promised by the debtor to the creditor that the object of mortgage will be owned by the holder of the Insurance right if injured promise. When implementing a credit agreement, if a situation that the debtor has indeed committed or is no longer able to fulfill all its obligations to the creditor, a separate agreement before the Notary on the "Submission of Guaranteed Guaranteed Viability" is settable."

Voluntary Guarantee Transfer Deed or otherwise known as a Deed of Settlement Agreement (Obligations) is an Agreement made by the Bank with the Customer or the Guarantor/Guarantee Owner of the debtor/guarantor's assets after in fact the debtor is no longer able to to return the obligations to the bank in accordance with the provisions in a previously created and signed credit agreement. Voluntary Guarantee Transfer Deed is an agreement to be used with additional agreements, Power of Attorney Selling, Selling Binding and Proxy Selling by Voluntary Mortgage Rights Deed and all debtor's liabilities to a bank that has been separated since the signing of the deed. In the theory of civil law, the disbursement by the debtor over the Voluntary Mortgage Rights is included in the category of juridical delivery (juridische levering) [11].

The Bank may freely sell the assets submitted by the debtor provided that the sale price of the asset exceeds the value of the delivery, the debtor shall not be entitled to claim any excess funds on the sale of the delivered assets, and vice versa if the sale proceeds of the delivered assets decreased or lower of the value of delivery when the sale is made, then the bank can no longer make claims against the debtor on the basis of deficiency of asset value it submitted it. In the aspect of responsibility theory, the voluntary surrender of Guaranteed Insurance is a form of responsibility of the debtor to the creditor because it is unable to perform the obligations that have been agreed previously. The inability of the debtor may occur intentionally (intentional tort liability), and can occur due to negligence (negligence tort liability).

The choice of credit settlement by means of voluntary guarantee delivery shows that business holder, especially banks, are less likely to settle disputes through courts or through auction process because: it is not cheap, open to the public to harm the good name of the debtor or creditor, time consuming old, and court decisions are often unpredictable. The voluntary surrender pattern is a pattern of settlement through non-litigation channels. Formal recognition of the existence of non-litigation channels to resolve disputes has 
been set forth in various laws and regulations prevailing in Indonesia.

\section{CONCLUSION}

Voluntary mortgage warranty transfer by the debtor to the creditor is reviewed from the legal aspect of the legal guarantee if the surrender is made during the implementation of the credit agreement that is formulated before the Notary under the Voluntary Guarantee Right Deed or the Financing Settlement Agreement (Obligations). Dispute resolution patterns outside the litigation or auction process are formally recognized in various laws and regulations. These provisions can form the basis for developing a dispute resolution pattern in the banking fields. The Mortgage Rights Law needs to be revised to synchronize with the provisions contained in the Banking Act. In parallel, voluntary mortgage warranty transfer can be developed into one of the most important legal principles of the future.

\section{ACKNOWLEDGMENT}

The author would like to thank all the parties who have helped and contributed in the writing of this article, both those who contribute in the form of funding and critical ideas. Hopefully this paper can be useful theoretically and practically for the addition and development of knowledge, especially in the field of legal science.

\section{REFERENCES}

[1] S. Sembiring, Hukum Perbankan, Mandar Maju, Bandung. 2012.

[2] Bahsan, Hukum Jaminan Dan Jaminan Kredit Perbankan Indonesia, Ed.1, cet.2, PT. Raja Grafindo Persada, Jakarta, 2008.

[3] Xu, Xuanhua, Z. Du, and Y. Chen, 'Study on Group Decision Support System for Bank Loan Project of Engineering Machinery Enterprise Based on Cloud Model', 2015, 370-80.

[4] A. Habib, Hak Tanggungan sebagai Lembaga Jaminan Atas Tanah, Mandar Maju, Bandung. 2000.

[5] L. Y. Suk, Government Guaranteed Small Business Loans and Regional Growth', Journal of Business Venturing, 33, 2018. 70-83.

[6] C. Adele, C. Fiondella, M. Maffei, and C. Zagaria, 'Managing Risk in Credit Cooperative Banks: Lessons from a Case Study', Management Accounting Research, 32, 2016. 1-15.

[7] J. Rawls, A Theory of Justice: Teori Keadilan, Yogyakarta: Pustaka Pelajar. 2006.

[8] A. Y. Hernoko, Hukum Perjanjian Asas Proporsionalitas dalam Kontrak Komersial, Yogyakarta: Laksbang Mediatama, 2008.

[9] Marbun, S. F., Eksistensi Asas-Asas Umum Penyelenggaraan Pemerintahan Yang Layak Dalam Menjellmakan Pemerintahan Yang Baik Dan Bersih Di Indonesia, Disertasi Program Pasca Sarjana Universitas Padjadjaran Bandung. 2001.

[10] Departemen Pendidikan dan Kebudayaan, Kamus Besar Bahasa Indonesia, Cet. II, Jakarta, 1989.

[11] Abdulkadir Muhammad, Hukum Perusahaan Indonesia, Citra Aditya Bakti, 2010. 